\title{
Food Intolerance and Malabsorption Syndrome in Children: Signs and Symptoms
}

\author{
Tetiana Yaroshevska* \\ Department of Childhood Diseases, SI Dnepropetrovsk Medical Academy HM of Ukraine, Ukraine
}

*Corresponding author: Tetiana Yaroshevska, Associate Professor, Department of Childhood Diseases, SI Dnepropetrovsk Medical Academy HM of Ukraine, Dnipro, Ukraine

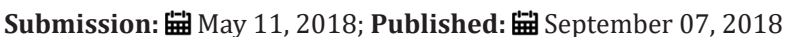

\section{Introduction}

Issues of food intolerance formation in children are currently relevant due to high prevalence and difficulties with diagnostics [1-3]. Environmental pollution can negatively affect quality of food. There are a significant number of food components, which human body is not adapted to during the evolution (e.g. stabilizers, preservatives, transgenic fats, refined products, etc.). Children have anatomical and physiological features that are predisposing to formation of malabsorption syndrome, such as delayed start of digestive enzyme systems, violation of gastrointestinal motility regulation, immaturity of the intestinal microbiocenosis, high intestinal penetration and others.

Clinical manifestations of food intolerance are low-specific and can be latent. Patients are being miss-supervised by various specialists for years because of secondary disorders, whereas the cause of suffering remains unclear and the prescription of treatment is being delayed [3]. The most common clinical manifestation of malabsorption syndrome is polyfecalia and this symptom can be easily recognized by careful anamnesis collection. However, it is necessary to know that the stool can keep unchanged in some children. It is also important to know the other symptoms that indicate malabsorption-polyhypovitaminosis, iron-deficiency anemia, hypocalcemia-related spasmophilia, lack of body mass, reduction of height and delay in sexual development. Accumulation of under-digested metabolic products leads to the formation of intoxication syndrome with the next manifestations: headaches, nausea, fatigue, irritability, tearfulness, pallor of the skin, periorbital cyanosis. Intoxication can also cause tachycardia, aphthous stomatitis, violations of biochemical indicators of liver and kidney function $[2,4]$. Toxic damage of the nervous system has characteristic symptoms, such as tics, tremor of the extremities and eyelids. Also, gastro-esophageal reflux is possible, as well as the formation of a pain syndrome-often recurrent abdominal and pelvic pain or cystalgia.

The most common causes of malabsorption syndrome are cystic fibrosis, celiac disease, disaccharidase insuffiency and intolerance to cow milk proteins. Very often changes in microscopic ex amination of feces come to be a key to understand the syndrome of malabsorption. Violation of protein digestion is characterized by an increase in feces $\mathrm{pH}$, putrefactive odor and creatorrhea. Carbohydrate malabsorption is characterized by an acidic smell, decrease in $\mathrm{pH}$ level, and amylorrhea. And in cases of fat malabsorption, steatorrhea occurs. However, if steatorrhea takes place, doctors almost always study sweat chlorides to exclude cystic fibrosis, but amylorrhea and creatorrhorea attract doctor's attention rarely and are usually explained by the presence of an intestinal dysbacteriosis or small bowel bacterial overgrowth syndrome. Probably, practical doctors are less aware of the high frequency of gluten enteropathy, disaccharidase insuffiency or intolerance to cow milk proteins. Currently the capabilities of laboratory diagnosis of these diseases have improved. It would be appropriate to use study of cow milk protein antibodies, antiendomysial and anti-tissue transglutaminase IgA antibodies, hydrogen respiratory test and also genetic test of C/T (13910) polymorphism as a first stage of screening test for adult-type hypolactasia [3]. At the same time, it can be assumed that along with lactose intolerance, sucrase deficiency possible in children, but its diagnostics requires elaboration, and work in this direction is prospecting [5].

\section{Conclusion}

Mentioned above does not include all the causes of malabsorption syndrome and food intolerance in children. Diagnostic research can be long and complicated. But usage of a simple laboratory diagnostic algorithm in children with clinical manifestations of malabsorption syndrome allows exclude or confirm the most common causes of this syndrome and improve approaches to drug therapy and diet therapy, as well as improve the quality of life of sick children.

\section{References}

1. Cheetham T, Baylis PH (2002) Diabetes insipidus in children: pathophysiology, diagnosis and management. Paediatr Drugs 4(12): 785-796.

2. Majzoub DTB, Josh A (2012) Diabetes insipidus. In: Nelson Treaty of Pediatrics, pp. 1954-1956. 
3. Di Iorgi N, Napoli F, Allegri AEM, Olivieri I, Bertelli E, et al. (2012) Diabetes insipidus-diagnosis and management. Horm Res Paediatr 77(2): 69-84.

4. Abu-Libdeh A, Wexler ID, Dweikat I, Zangen D, Abu-Libdeh B (2017) A novel mutation in the AVPR2 gene in a family with nephrogenic diabetes palestinian insipidus. JCS 1(1): E1-E3.

5. Garcia Garcia E (2011) Diabetes insipidus concept. Protoc Asoc Spanish Pediatrics 1(1): 44-53.

6. Diabetes insipidus F (2002) Laczi: etiology, diagnosis, and therapy. ORV Hetil 143(46): 2579-2585.

7. De Los Santos MA, Aguila CM, Red MI, Falen JM, Nunez O, et al. (2016) Central diabetes insipidus: clinical profile suggests that organicity in Peruvian children: Lima -Peru 2001-2013. J Pediatr Endocrinol Metab 29(12): 1353-1358.

8. Arima H, Azuma Y, Morishita D (2016) Hagiwara central diabetes it is insipidus. Nagoya J Med Sci 78(4): 349-358.

9. Avner SR (2012) Nephrogenic diabetes insipidus. In: Nelson Treaty of Pediatrics, pp. 1882-1883.

10. Böckenhauer D, Bichet DG (2017) Nephrogenic diabetes insipidus. Curr Opin Pediatr 29(2): 199-205.
11. Dabrowski E, Kadakia R (2016) Diabetes insipidus D. Zimmerman in infants and children. Best Pract Endocrinol Metab Res Clin 30(2): $317-$ 328.

12. Böckenhauer D, Bichet DG (2015) Pathophysiology, diagnosis and management of nephrogenic diabetes insipidus. Nat Rev Nephrol 11(10): 576-588.

13. Schernthaner MH-Reiter, Stratakis CA, Luger A (2017) Genetics of diabetes insipidus. Endocrinol Metab Clin North Am 46(2): 305-334.

14. Lu Haj (2017) Diabetes Insipidus BT -Aquaporins. In: Yang B (Ed.), Dordrecht: Springer, Netherlands, Europe, pp. 213-225.

15. Kochhar RS (2017) Diabetes insipidus S Ball. Medicine (Baltimore) 45(8): 488-491.

16. Jain V, Aathira R (2016) Diabetes insipidus in children. Journal of Pediatric Endocrinology and Metabolism 29: 39.

17. Di Iorgi N, Morana G, Napoli F, Allegri AEM, Rossi A, et al. (2015) Management of insipidus and adipsia in the child diabetes. Best Pract Endocrinol Metab Res Clin 29(3): 415-436.
Creative Commons Attribution 4.0 International License

For possible submissions Click Here

\section{Submit Article}

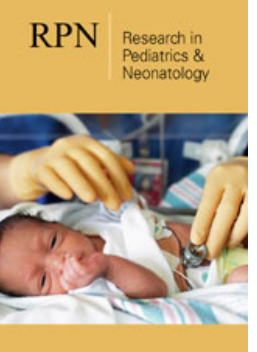

\section{Research in Pediatrics \& Neonatology}

\section{Benefits of Publishing with us}

- High-level peer review and editorial services

- Freely accessible online immediately upon publication

- Authors retain the copyright to their work

- Licensing it under a Creative Commons license

- Visibility through different online platforms 